\title{
WILLINGNESS TO PAY: A PROXY TO PRODUCT PRICE
}

\author{
Tongam Sihol Nababan', Raya Panjaitan'2, Ferry Panjaitan ${ }^{3}$, Kornel Munthe ${ }^{4}$ \\ 1,2,3Faculty of Economics, Universitas HKBP Nommensen, Medan \\ 4Faculty of Economics, Universitas Katolik St. Thomas, Medan \\ E-mail: tsnababan@gmail.com
}

\begin{abstract}
Information about willingness to pay (WTP) essentially aims to protect consumers from the abuse of monopoly power owned by companies in the supply of quality products and prices. The consumer's WTP of a product can be an appropriate basis in determining the pricing policy for a product because he can reveal the true value or price of the product based on consumer perception. The price proxy with the WTP can still meet the assumption of the traditional demand model (Marshallian demand model) where the price is not set (regulated) by the government. WTP can be obtained by using a contingent valuation method.
\end{abstract}

Keywords: willingness to pay, product, consumer, contingent valuation.

\section{INTRODUCTION}

In general, willingness to pay (WTP) is the amount of money that a consumer can pay to obtain an item of the product (UNEP, 1995). Zhao \& Kling (2005) states that WTP is the maximum price of a product that consumers want to buy at a certain time. Further, Horowith \& McConnell (2001) more emphasize on the ability of consumers to buy goods or services. WTP is a price at the consumer level that reflects the value of goods or services and sacrifice to obtain it (Simonson \&Drolet, 2003). According to Turvey \& Anderson (1997), as cited by PSE-KP UGM (2002), willingness to pay (WTP) for a product can be an appropriate basis in determining the pricing and investment policies. Dinauli (1999), Nam \& Son (2005) also suggest that consumers' WTP on a product can reveal the true value or price of the product based on consumer perception.

To understand the concept of WTP, it must be started from the concept of utility, which is the benefit or satisfaction of consumers of goods or services at a certain time. Everyone always tries to maximize its utility with a certain income, which determines the amount of demand for goods or services to be consumed. Demand is defined as the number of goods or services that consumers want to buy or pay at a certain price and time (Perloff, 2004). The utility can be obtained by a consumer concerning relation to the price paid which can be measured by WTP. A sum of money to be paid by consumers will show the utility indicators obtained from the goods or services (PSE-KB UGM, 2002).

The concept of measuring utility by using WTP has been mostly done especially for public goods or public services that are not traded (non-traded or non-marketed) (Delaeny \& O'Toole, 2004a; Delaeny \& O'Toole, 2004b Fernandez et al. 2004; Zhao \& Kling, 2004; Crooker \& Herriges, 2004; Murphy, et al. 2005; Morancho, et al. 2005). The reason for the use of WTP in public goods or services is because their prices or market values fail to be reflected in the public or consumers or because of the absence of market transactions (Crooker \& Herriges, 2004; Cuena, et al. 2004). Another reason given by Pattanayak, et al (2006) is due to the unavailability of data from consumer demand. Therefore, to overcome this problem a WTP survey can be used.

In this paper, we wish to describe and to stress how the WTP can be applied as a proxy of the product price. 


\section{METHOD}

This paper is written based on a literature review, conceptual analysis, and describe some previous studies. Here, the literature review and conceptual analysis are intended to identify key aspects of building a method of WTP.

\section{THEORITICAL REVIEW}

Theoretically, Hokby \& Sodergvist (2001) and Anstine (2001) explain that the WTP method is made to show choices between different price and quantity combinations, in which the utility can be maximized by a consumer. By using the Marshallian demand function, they express the relationship between utility and WTP. For example, a consumer is assumed to be able to maximize his utility function:

$$
u=U(x, z) \text {, }
$$

$x$ is private goods, and $z$ is public goods (for example, environmental services). This utility maximization is obtained with a budget constraint:

$$
q x+p z=y
$$

$q$ is the market price of private goods $x$, and $p$ is the price for $z$, while $y$ is income. The completion of this maximization can be done using the Lagrange method, so that the Marshallian demand function $(D)$ is obtained, for example for item $z$ and the indirect utility function $(v)$, as follows:

$$
\begin{aligned}
& z=D z(q, p, y) \\
& v=V(q, p, y)
\end{aligned}
$$

In the WTP study, budget consideration becomes a restriction in the provision of public goods, for example, goods " $z$ ", so that a consumer cannot maximize the utility of $U(x$, $z$ ) for goods $z$ optimally. This becomes an argument that allows goods " $z$ " to be made in the form of an indirect utility function that focuses their analysis on the welfare effect or value generated due to the change of the provision of public goods. This change in value or welfare is estimated as WTP, where WTP for goods " $z$ " increases, for example from z0 to z1 which implicitly obtained from the indirect utility function:

$V\left(q, y-W T P, z_{1}\right)=V\left(q, y, z_{0}\right)$.

Here, WTP can be likened with a substitute for payment or a substitute for price. In this case WTP will be estimated from the consumer's answer to a WTP question. Consumers are asked to accept or refuse to pay a certain price due to changes in goods " $z$ ". Another alternative can be done with open-ended questions and consumers are asked to specify what is the maximum WTP to obtain changes in goods " $z$ ".

Haneman (1991) has introduced the theory of random utility in studies of WTP, assuming that the utility function is linear with income. He demonstrate how to obtain measures of social welfare (ie: average and median of WTP) starting with "dichotomous valuation" questions (questions with "yes" or "no" answers). For example, the utility function of a consumer is:

$$
U(Y, X, Q)+\varepsilon
$$

$\mathrm{Y}$ is income, $\mathrm{X}$ is a socioeconomic characteristic, $\mathrm{Q}$ is an environmental asset, and $\varepsilon$ is the error term. When a consumer is offered an amount of money (A) for a change in $Q$, for example, $Q_{0}$ to $\mathrm{Q}_{1}$, he will accept the offer if:

$$
U\left(Y-A, X, Q_{1}\right)+\varepsilon \geq U\left(Y, X, Q_{0}\right)+\varepsilon .
$$

Thus, a consumer's response can be a random variable with a cumulative $(\mathrm{G})$ distribution function of WTP against the number of A or GWTP (A). Therefore, the probability that the consumer wants to accept at price of A becomes: Prob. $\{$ Yes $\}=$ Prob. $\{A \leq W T P)=1-$ GWTP $(A)$. 
Furthermore, this Haneman model is applied by asking consumers whether they want to pay a certain value for public goods that are not traded (non-marketed).

Wang \& Whittington (2006) provides a general WTP valuation framework for public goods (for example, environmental quality). For example, an individual's utility value for environmental quality $\left(E_{0}\right)$ is:

$$
V_{0}=V\left(Y, P, E_{0}, Z, \varepsilon_{1}\right)
$$

$Y$ is income, $P$ is the price, $Z$ is socioeconomic variables, and $\varepsilon 1$ is other factors not included in $Y, P, E 0$, and $Z$. When the level of environmental quality increases from E0 to E1, and individual utilities change be $\mathrm{V} 1=\mathrm{V}(\mathrm{Y}, \mathrm{P}, \mathrm{E} 1, \mathrm{Z}, \varepsilon 1)$. Individuals are assumed to be willing to pay some WTP for changes in the quality of the environment, then the equation becomes:

$$
V 0=V\left(Y-W T P, P, E_{1}, Z, \varepsilon_{1}\right)=V_{0}=V\left(Y, P, E_{0}, Z, \varepsilon_{1}\right)
$$

Then the following WTP equation is obtained:

$W T P=W T P\left(Y, P, E_{0}, E_{1}, Z, \varepsilon_{1}\right)=E[W T P]+\varepsilon_{2}$

$E$ [.] is a transformation expectation, and $\varepsilon_{2}$ is the error term of the individual WTP economic value.

The formulations of Hokby \& Soderqvist (2001), Anstine (2001), and Haneman (1984) above show that the price of a product is replaced or proxied by the WTP variable, while Wang \& Whittington (2006) only emphasizes the WTP value from changes in the quality of the public good, while the price variable still exists.

Studies on the use of WTP in public goods or services have been carried out, for example in the fields of general education (Tan, et al. 1984; LSMS, 1989), food safety (Rozan, et al. 2004), the television and broadcasting service industry (Anstine, 2001; Delaeny \& O'Toole, 2004b), recyclable products (Cuena, et al. 2004), drinking water services (Nam \& Son, 2005; Pattanayak, et al. 2006), environmental services (Hokby \& Sodergvist, 2001), air quality improvement (Wang \&Whittington, 2006; Kumar \& Rao, 2006), preservation of lake and beach environments (Alberini, et al. 2004), crime control programs (Cohen, et al. 2001), urban transportation (Dinauli, 2001), quality of river water (Widayanto, 2001), determination of toll road tariffs (Silaen, 2000), elderly health (longetivity) (Johnson, et al. 2006), and the determination of regional electricity tariffs (Sugiyanto, 2002).

\section{DISCUSSION}

In a situation where consumers do not have many choices to determine the utility of a public good or service, the consumer's judgment will be reflected in the amount of whether he is willing or willing to pay (WTP). For example, electrical energy, with the main basis of efficient allocation is marginal cost pricing: if electricity prices are set at the same marginal cost, consumers are willing to pay or have the willingness to pay for additional electricity usage at the cost of providing additional electricity services. If electricity prices are lower than marginal costs, this will stimulate excessive use of electricity, and over-investment will occur which will cause a misallocation of scarce economic resources. Conversely, if the price is set higher than the marginal cost, it will reduce the use of electricity which will then reduce the welfare of the community.

Nababan (2008) in his research on estimating household electrical energy demand, to proxy electricity prices, has used an approach with the contingent valuation method with closed-ended referendum elicitation format (bidding game format). He adopted and developed this method as has been used by the EEPSEA (Economy and Environment Program for Southeast Asia), ADB (Asian Development Bank), and World Bank institutions (Whittington, 1996; ADB, 1999; Tapvong \& Kruavan, 2000; Yaping, 2000; Nam \& Son, 2005). The contingent valuation method is done by creating a questionnaire that contains 1) research background, 2) the profile or socioeconomic characteristics of the respondent, 3) the use of 
household electrical energy, 4) closed-ended referendum elicitation format to obtain the WTP of household respondent's electrical energy.

To obtain an estimated WTP (eliciting WTP) from a public good or service, a stated or revealed preference survey method or technique can be used. The stated preference (SP) method or technique is a method used to measure people's or consumers' preferences if they are given alternatives or choices. Basically in the SP method, consumers are asked to answer questions about the value of goods / services (Pattanayak, et al. 2006; Murphy, et al. 2005; Kumar \& Rao, 2006; Silaen, 2000). The SP method provides information based on the hedonic principle that goods or services have value because of their attributes, which are designed to measure basic utility or preferences so that they are consistent with consumer WTP (Johnson, et al. 2006).

In its operations, SP surveys can be carried out by the Contingent Valuation (CV) method or often also called WTP Survey, which can directly obtain WTP values from consumers (Pattanayak, et al. 2006). The basic approach of the CV method is to explain a hypothetically specific policy scenario as outlined in a questionnaire, and then be asked or submitted to consumers to find out the actual WTP of particular goods or service (Johnson, et al. 2006); Fernandez, 2004; Morancho, et al. (2005). According to Pattanayak, et al. (2006), there are two benefits of conducting a CV survey, namely: (1) it can obtain opinions and preferences of consumers to a product or service directly, (2). the CV method is a practical form of a field experiment.

To assess the WTP from consumers, several CV method formats that can be done and outlined in the questionnaire, namely: (1) open-ended elicitation format, (2) closed-ended referendum elicitation format or bidding game format, and (3) payment card elicitation, or sequential referendum method, or discrete choice method (Kumar \& Rao, 2006; Widayanto, 2001; Delaeny \& O'Toole, 2004a).

Open-ended elicitation format, which is a method that is done by asking directly to consumers what the maximum amount of value to be paid for an item or service. The advantage of this method is that consumers do not need to be given instructions that can influence the value to be given. This method does not use the initial value offered so that there will not be an initial data bias (starting point bias). The disadvantage of this method is that the value given by the consumer is inaccurate, sometimes too large or too small so that it cannot describe the true value of the WTP.

Closed-ended referendum elicitation format (bidding game format), conducted by consumers being asked to give a yes / agree or no/disagreement option (called a dichotomous choice) to pay a certain amount of money that is proposed as a starting point. If the answer is yes, then the amount of the bid value will be increased to the agreed level. If the answer is no, the offer value is lowered to the agreed amount. The strength of this method is that it gives consumers more time to think about WTP, while the weaknesses may contain bias in the initial data (starting point bias).

Payment card elicitation (sequential referendum method, or discrete choice method). In this method, consumers are asked to choose a realistic WTP according to their preferences for several things offered in the form of cards. To develop the quality of this method can be given a kind of benchmark value (benchmark) that describes the value issued by someone with a certain income for an item or service. The advantages of this method can provide stimuli that will be given without having to be intimidated with a certain value. The disadvantage is that consumers can still be affected by the amount of value printed on the card offered. 


\section{CONCLUSION}

Some reasons that strengthen the use of the WTP variable as a proxy for the price variable are as follows: (1) willingness to pay (WTP) for a product can be an appropriate basis in determining pricing and investment policies and consumers' WTP for a product can reveal the true value or price of the product based on consumer perception, (2) price proxy with WTP can still fulfill the assumption of the traditional demand model (Marshallian demand model) with the price set not (regulated) by the government. Then, the CV method used to obtain the WTP value has two benefits, namely: (1) it can obtain consumer opinion and preferences for an item or service directly, (2) the CV method is a practical form of field experimentation.

\section{REFERENCES}

ADB (Asian Development Bank). (1999). Handbook for the Economic Analysis of Water Supply Projects, http://www.adb.org//

Alberini, A., Rosato, P., Longo,A., \& Zanatta, V. (2004). Information and Willingness To Pay in a Contingent Valuation Study: The Value of S. Erasmo in Lagoon of Venice. Sustainability Indicators and Environtmental Valuation, 1-46. http:// papers.ssrn.com/

Anstine, D. B. (2001). How Much Will Consumers Pay ? A Hedonic Analysis of the Cable Television Industry. Review of Industrial Organization, 19, 129-147.

Cohen, M. A., Rust, R. T., Steen, S., \& Tidd, S. T. (2001). Willigness To Pay For Crime Control Programs. The National Instutute Justice, Office of Justice Programs, U.S. Department of Justice, 1-44, http:/ / papers.ssrn.com.

Crooker, J. R., \& Herriges, J. A. (2004). Parametric and Semi-Nonparametric Estimation of Willingness To Pay in the Dichotomous Choice Contingent Valuation Framework. http:/ / papers.ssrn.com.

Cuena, E. C., Garcia-Gallego, A., Georgantzis, N., \& Sabat, G. (2004). An Experimental Validation of Hypothetical Willingness To Pay for a Recyclable Product. Environtmental and Resource Economics, 27 (3), 313-335.

Delaney, L., \& O'Toole, F. (2004). Eliciting Household and Individual Willingness To Pay and Aggregation. Department of Economics, University of Dublin, Trinity College, Dublin, Ireland, 1-49. http:/ / papers.ssrn.com/

Delaney, L., \& O'Toole, F. (2004). Irish Public Service Broadcasting : A Contingent Valuation Analysis. The Economic and Social Review, 35 (3), 321-350.

Dinauli, H. (2001). Analisis Ability To Pay dan Willingness To Pay Tarif Angkutan Kota (Studi Kasus Kotamadya Medan. Master Theses. Bandung: ITB Central Library. http://www.lib.itb.ac.id/

Fernandez, C., Leon, C. J., Steel, M. F. J., \& Vazquez-Polo, F. J. (2004). Bayesian Analysis of Interval Data Contingent Valuation Models and Pricing Policies. Journal of Business $\mathcal{E}$ Economic Statistics, 22 (4), 431-442.

Haneman, W. M. (1991). Willingness To Pay and Willingness To Accept : How Much Can They Differ?. The American Economic Review, 81 (3), 635-647.

Hokby, S., \& Soderqvist, T. (2001). Elasticities of Demand and Willingness To Pay for Environtmental Services in Sweden. 11 th Annual Conference of the European Association of Environtmental and Resource Economists. Southampton, UK, 1-37. http://papers.ssrn.com/

Horowitz, J. K., \& McConnell, K. E. (2001). Willingness To Accept, Willingness To Pay and The Income Effect. Department of Agricultural and Resource Economics. University of Maryland, 1-22. http:/ / papers.ssrn.com/paper/id=261107/ 
Johnson, F. R., Desvousges, W. H., Ruby, M. C., Stieb, D., DeCivita, P., \& Bingham, M. F. (2006). Eliciting Stated Health Preferences : An Application To Willingness To Pay For Longevity. Triangle Economic Research Canada, 1-25. http:// papers.ssrn.com/.

Kumar, S., \& Rao, D. N. (2006). Willingness To Pay Estimates of Improved Air Quality : A Case Study in Panipat Thermal Power Station Colony, India. TERI School of Advanced Study, New Delhi \& Centre for Economic Studies and Planning, School of Social Sciences, Jawaharlal Nehru University, New Delhi, 1-17. http:/ / papers.ssrn.com/

LSMS (Living Standards Measumement Study). (1989). The Willingness To Pay for Education in Developing Countries : Evidence from Rural Peru. LSMS Working Paper ,54. http://www.worldbank.org

Moranco, A. B., Fuertos-Eugenio, A. M., Saz-Salazar,S. (2005). A Comparison of Empirical Models Used to Infer the Willingness To Pay in Contingent Valuation. Empirical Economics, 30, 235-244.

Murphy, J. J., Allen, P. G., Stevens, T. H., \& Weatherhead, D. (2005). A Meta-Analysis of Hypothetical Bias in Stated Preperence Valuation. Environtmental and Resource Economics, 30, 313-325.

Nababan, T. S. (2008). Permintaan Energi Listrik Rumah Tangga (Studi Kasus pada Pengguna Kelompok Rumah Tangga Listrik PT PLN (Persero) di Kota Medan. Disertasi. Semarang: Universitas Diponegoro.

Nam, P. K., \& Son, T. V. H. (2001). Recreational Value of the Coral Surrounding the Hon Mun Islands in Vietnam : A Travel Cost and Contingent Valuation Study. Research Report, 84-107, Economy and Environtment Program for Southeast Asia (EEPSEA), Singapore, http://www.eepsea.org

Nam, P. K., \& Son, T. V. H. (2005). Household Demand for Improved Water Services in Ho Chi Min City : A Comparison of Contingent Valuation and Choice Modelling Estimates. Research Report No. 2005-RR3, pp.1-23, Economy and Environtment Program foe Southeast Asia (EEPSEA). http://www.eepsea.org

Pattanayak, S., Berg, C., Yang, J., \& Van Houtven, G. V. (2006). The Use of Willingness To Pay Experiments : Estimating Demend for Piped Water Connections in Sri Lanka. World Bank Research Working Paper 3818,1-47. http:/ / www.worldbank.org

Perloff, J. M. (2004). Microeconomics, Third Edition, New York : Pearson Education Inc.

PSE-KP UGM (Pusat Studi Ekonomi-Kebijakan Publik Universitas Gadjah Mada). (2002). Analisis Tarif Listrik Regional di Jawa Tengah dan D. I. Yogyakarta (Laporan Akhir). Kerjasama PSE-KP UGM \& PT. PLN (Persero) Unit Bisnis Distribusi Jawa Tengah dan Yogyakarta.

Rozan, A., Stenger, A., \& Willinger, M. (2004). Willingness To Pay for Food Safety ; An Experimental Investigation of Quality Certification on Bidding Behaviour. European Review of Agricultural Economics,31 (4), 409-425.

Silaen, A. M. P. (2000). Pendekatan Willingness To Pay Dalam Penentuan Tarif Tol. Thesis. Program Pascasarjana Bidang Ilmu Teknik Sipil. Universitas Indonesia (unpublished).

Simonson, I., \& Drolet, A. (2003). Anchoring Effects on Consumers' Willingness To Pay and Willingness To Accept. Research Paper Series No. 1787, 1-38. Stanford Graduate School of Business, http:/ / papers.ssrn.com/

Sugiyanto, C. (2002). The Use of Willingness To Pay Approach to Determining the Regional Electricity Tariff. Center for Economic and Public Policy Studies, Gadjah Mada University, Yogyakarta, http://pskep.ugm.ac.id

Tan, J., Lee, K. H., \& Mingat, A. (1984). User Charges for Education : The Ability and Willingness To Pay in Malawi. World Bank Staff Working Papers, 661, 1-124. http://www.worldbank.org 
Taptong, C., \& Kruavan, J. (2000). Water Quality Improvements : A Contingent Valuation Study of The Chao Phraya River. Research Report, 1-29, Economy and Environtment Program foe Southeast Asia (EEPSEA), http:// www.eepsea.org

Wang, H., \& Whittington, D. (2006). Willingness To Pay for Air Quality Improvement in Sofia, Bulgaria. Development Research Group, World Bank, 1-27. http:// papers.ssrn.com/

Whittington, D. (1996). Administering Contingent Valuation Surveys in Developing Countries (Special Papers), 1-9. Economy and Environtment Program for Southeast Asia (EEPSEA). http://www.eepsea.org

Widayanto, Y. (2001). Analisis Kebijakan Memperbaiki Kualitas Air Kali Brantas Dengan Menggunakan Metode Contingent Valuation, Thesis, Magister Perencanaan \& Kebijakan Publik, Fakultas Ekonomi, Universitas Indonesia (unpublished).

Yaping, D. (2000). The Value of Improved Water Quality For Recreation In East Lake, Wuhan, China : An Application of Contingent Valuation and Travel Cost Methods. Research Report,1-19, Economy and Environtment Program foe Southeast Asia (EEPSEA). http://www.eepsea.org

Zhao, J., \& Kling, C. L. (2004). Willingness To Pay, Compensating Variation, and the Cost of Commitment. Economic Inquiry, 42 (3), 503-517. 